medRxiv preprint doi: https://doi.org/10.1101/2020.07.21.20158634; this version posted July 22,2020 . The copyright holder for this preprint (which was not certified by peer review) is the author/funder, who has granted medRxiv a license to display the preprint in perpetuity.

It is made available under a CC-BY-NC-ND 4.0 International license .

\title{
Phenotypical predictors of Restless Legs Syndrome in pregnancy and their association with basal
} ganglia and the limbic circuits

Natalia Chechko ${ }^{1,2,6 *}$, Jeremy Lefort-Besnard ${ }^{1}$, Tamme W. Goecke ${ }^{7,8}$, Markus Frensch ${ }^{9}$, Patricia Schnakenberg ${ }^{1,2}$, Susanne Stickel ${ }^{1,2}$, Danilo Bzdok ${ }^{3,4,5}$

1. Department of Psychiatry, Psychotherapy, and Psychosomatics, RWTH Aachen University, Pauwelsstrasse 30, 52070 Aachen, Germany

2. Jülich Aachen Research Alliance (JARA) - Translational Brain Medicine, Pauwelsstrase 52070 Aachen, Germany

3. Parietal Team, INRIA, CEA, Université Paris-Saclay, 3 rue Joliot-Curie 91192, Gif-sur-Yvette, France

4. Department of Biomedical Engineering, Montreal Neurological Institute, Faculty of Medicine, McGill University, 845 Sherbrooke St W, Montreal, Quebec, Canada

5. Mila - Quebec Artificial Intelligence Institute, 6666 St Urbain St, Montreal, Quebec, Canada

6. Institute of Neuroscience and Medicine, Brain \& Behaviour (INM-7), Research Centre Jülich, Wilhelm-Johnen-Strasse, 52425 Jülich, Germany

7. RoMed Hospital Rosenheim, Department of Obstetrics, Pettenkoferstraße 10, 83022 Rosenheim, Germany

8. Department of Gynaecology and Obstetrics, RWTH Aachen University, Pauwelsstrasse 30, 52070 Aachen, Germany

9. Klinikum Mutterhaus der Borromäerinnen gGmbH, Abteilung für Gynäkologie u. Geburtshilfe, Feldstraße 16, 54290 Trier, Germany

* Corresponding author: Natalia Chechko (nchechko@ukaachen.de)

Keywords: Pregnancy, restless legs syndrome, structural MRI, machine learning, pattern learning 
medRxiv preprint doi: https://doi.org/10.1101/2020.07.21.20158634; this version posted July 22, 2020. The copyright holder for this preprint (which was not certified by peer review) is the author/funder, who has granted medRxiv a license to display the preprint in perpetuity.

It is made available under a CC-BY-NC-ND 4.0 International license.

\section{ABSTRACT}

The pregnancy-related restless legs syndrome (RLS) is thought to have a multifactorial etiology. However, the

4 reason behind the manifestation of RLS during pregnancy remains largely elusive.

5 A neurological and obstetrical cohort of 308 postpartum women was screened for RLS symptoms twice: 1 to

66 days (T0) and 12 weeks postpartum (T1). 57 participants were identified as affected by pregnancy-associated

7 RLS. The clinical and anamnestic indicators of the condition were assessed by a pattern-learning classifier

8 trained to predict the RLS status. Structural MRI was obtained from 25 of the 57 participants with RLS history

9 in pregnancy. In this sample, a multivariate two-window algorithm was employed to systematically chart the

10 relationship between brain structures and phenotypical predictors.

11 The RLS prevalence rate in our sample was $19 \%(n=57)$, with the women suffering from RLS being older,

12 more often unmarried, affected by gestational diabetes and having been more exposed to stressful life events.

13 A history of RLS and the severity and frequency of repetitive compulsive movements were found to be the 14 strongest predictors of RLS manifestation. In the RLS group, high cortisol levels, being married and receiving 15 iron supplements were found to be associated with increased volumes in the bilateral striatum.

16 Investigating pregnancy-related RLS in a frame of brain phenotype modes may help shed light on the 17 heterogeneity of the condition. 
medRxiv preprint doi: https://doi.org/10.1101/2020.07.21.20158634; this version posted July 22, 2020. The copyright holder for this preprint (which was not certified by peer review) is the author/funder, who has granted medRxiv a license to display the preprint in perpetuity.

It is made available under a CC-BY-NC-ND 4.0 International license.

\section{INTRODUCTION}

Restless legs syndrome (RLS) is a common sensorimotor disorder with a 5-10\% prevalence in the adult population (Ohayon et al., 2012). Clinically, this condition is characterized by 1) an urge, triggered by unpleasant sensations, to move the legs, 2) momentary relief following movement, 3) worsening of the sensations with rest, and 4) a tendency for the sensations to occur in the evening or at night.

With two recognized forms, primary (idiopathic) and secondary, RLS (in both of its forms) is considered to be a continuous spectrum with a genetic contribution at one end and an environmental or comorbid disease contribution at the other (Trenkwalder et al., 2016). While idiopathic (primary) RLS is thought to be strongly influenced by genetic predisposition (Winkelmann et al., 2007), the secondary form of the condition is linked to disorders such as neurodegenerative disorder, peripheral neuronal diseases, metabolic disorders, iron deficiency, anemia and diabetes (Trenkwalder et al., 2016). Another common condition associated with RLS is pregnancy.

Largely a transitory condition, pregnancy-related RLS tends to increase from $0 \%$ before pregnancy to $23 \%$ in the third trimester (Gupta et al., 2016; Srivanitchapoom et al., 2014). Experience of RLS in a previous pregnancy and family history of RLS are strong predictors of the manifestation of pregnancy-related RLS symptoms during the ongoing pregnancy (Cesnik et al., 2010). Along with the genetic predisposition, physiological adaptations during pregnancy contribute crucially to the manifestation of RLS (Srivanitchapoom et al., 2014). Changes such as the dramatic increases in estrogen and progesterone levels (Duarte-Guterman et al., 2019), insulin resistance (Sonagra et al., 2014), hypervolemia (Duarte-Guterman et al., 2019), weight gain (Gao et al., 2009) and increased iron use (Haider et al., 2013) can render pregnant women particularly susceptible to the development of RLS symptoms.

The diagnosis of RLS in pregnancy (analogous to other forms of RLS) is based on the criteria developed by the International Restless Legs Syndrome Study Group (IRLSSG), according to which RLS is characterized by a number of neurological and other clinical indicators including the severity and frequency of repetitive compulsive movements as well as sleep and mood disturbances (Horiguchi et al., 2003). Pregnancy-related RLS is not only a neurological condition but also an obstetrical one. In particular, pregnancy-related RLS is linked to gestational diabetes mellitus (Trenkwalder et al., 2016) or pregnancy-induced hypertension (Ma et al., 2015). Thus, the manifestation of RLS in pregnancy may herald the risk of cardiovascular and metabolic diseases. In addition, multiparity (Berger et al., 2004), anemia and age (RLS is seen more frequently in older women) (Chen et al., 2012; Ohayon and Roth, 2002; Tunç et al., 2007) have been suggested to be further phenotypical predictors of pregnancy-related RLS. Finally, RLS frequently co-occurs with psychiatric disorders, particularly with affective disorders (Kallweit et al., 2016). In the context of pregnancy and childbirth, pre-pregnancy RLS has been found to be linked to perinatal depression (Wesström et al., 2014). 
medRxiv preprint doi: https://doi.org/10.1101/2020.07.21.20158634; this version posted July 22, 2020. The copyright holder for this preprint (which was not certified by peer review) is the author/funder, who has granted medRxiv a license to display the preprint in perpetuity. It is made available under a CC-BY-NC-ND 4.0 International license.

1 al., 2014). To understand this condition, the complex interaction of clinical, environmental and anamnestic aspects needs to be taken into account.

3 In a large neurological and obstetrical sample of 308 early-postpartum women, we sought to investigate a number of possible neurological, obstetrical and anamnestic phenotypical predictors of RLS in pregnancy (e.g. history of RLS, clinical character of symptoms, age, gestational diabetes or hypertension, stressful life events (SLE), socioeconomic characteristics, multiparity, duration of pregnancy and child's weight). Adding a brain structure analysis, we assessed the phenotypical predictors of RLS in pregnancy in a brain phenotype model. Here, an innovative multivariate pattern-learning algorithm (involving canonical correlation analysis or CCA) was employed to conjointly characterize patterns of brain structure and the phenotypical predictors of RLS, facilitating an objective assessment of their complex interplay.

\section{METHODS}

Study participants and clinical and neuropsychological assessments

14 A total of 308 women were recruited in the Department of Gynecology and Obstetrics at the University Hospital Aachen within 1 to 6 days of childbirth (T0) (Figure 1) between January 2016 and January 2018. The exclusion criteria were alcoholic or psychotropic substance dependency or use during pregnancy, antidepressive or anti-psychotic medication during pregnancy, history of psychosis or manic episodes, depressive episode during the current pregnancy, and inadequate proficiency in German or English. To control for the exclusion criteria, a short non standardized clinical interview was conducted according to the DSM V criteria by an experienced psychiatrist (NC).

21 Following receipt of the participants' informed consent, all participants were screened for RLS symptoms in pregnancy based on the criteria of the International Restless Legs Syndrome Study Group (IRLSSG) (Allen et al., 2014) and by means of the Restless Legs Syndrome Rating Scale (IRLSS) (Allen et al., 2014). A detailed description of the study population is given in Tables 1A, 1B and 1C. In addition, voxel-based morphometric (VBM) measurements were collected from 25 participants with RLS history in pregnancy, aged 23-42 years, the remainder of the RLS group (32) not being eligible for the MRI. A detailed description of the sample that participated in the MRI experiment is given in Table 2 (please refer also to Figure 1 with the flowchart of inclusion into the study).

In addition to the IRLSS, the following questionnaires were used at T0: the Stressful Life Events Screening Questionnaire (SLESQ) (Goodman et al., 1998) was used as a self-report instrument to help assess the participants' encounter with 13 particularly traumatic experiences, and the Edinburgh Postnatal Depression 32 Scale (EPDS) (Cox et al., 1987) was used as a self-report instrument for the screening of postpartum 33 depression. Furthermore, the participants filled out a standardized questionnaire to help obtain anamnestic and 
medRxiv preprint doi: https://doi.org/10.1101/2020.07.21.20158634; this version posted July 22, 2020. The copyright holder for this preprint (which was not certified by peer review) is the author/funder, who has granted medRxiv a license to display the preprint in perpetuity.

It is made available under a CC-BY-NC-ND 4.0 International license .

1 pregnancy-related information, e.g. family history of psychiatric conditions, previous psychiatric history, income, marital status, complications during pregnancy or birth mode.

3 The second screening session for postpartum RLS symptoms took place 12 weeks after delivery (T1) when the IRLSS and EPDS were applied for the second time.

Hair samples were collected shortly after delivery (T0) and 12 weeks postpartum (T1) to assess the cumulative cortisol exposure over the last trimester of pregnancy and three months postpartum, respectively.

The study was conducted in compliance with the Helsinki Declaration and was approved by the local ethics committee of the Medical Faculty, RWTH Aachen University, Germany.

Hair sample collection and preparation

Hair cortisol and cortisone are widely regarded as biomarkers of chronic stress (Stalder et al., 2017). Hair samples were obtained from the posterior vertex of the head, stored in aluminum foil, and treated as described in Stalder and Kirschbaum [24]. $3 \mathrm{~cm}$ of hair was cut at each time point and approximately $50 \mathrm{mg}$ was weighed in a polypropylene sampling tube using a microbalance. Hair samples were washed with 2-propanol, extracted with a fourfold deuterium isotope-labeled internal standard of cortisol and methanol for $24 \mathrm{~h}$ and then analyzed with liquid chromatography triple quadrupole mass spectrometry using an ion trap (Agilent Technologies 1200 infinity series -QTRAP 5500 ABSciex). The limits of quantification were $0.05 \mathrm{ng} / \mathrm{mL}$ or $2 \mathrm{pg} / \mathrm{mg}$ hair, respectively.

MRI procedure and Voxel-based morphometry

21 The structural image was acquired with an anatomical 3D T1-weighted MPRAGE sequence (176 slices, TR= $2300 \mathrm{~ms}, \mathrm{TE}=1.99 \mathrm{~ms}, \mathrm{FoV}=256 \times 256 \mathrm{~mm}^{2}$, flip angle $=9^{\circ}$, voxel resolution $=1 \times 1 \times 1 \mathrm{~mm}^{3}$ ). The brain tissue was segmented into gray matter, white matter and cerebrospinal fluid, the resultant adjusted volume measurements representing the amount of gray matter corrected for individual brain size. Structural MRI data were preprocessed using the Computational Anatomy Toolbox (CAT12) and SPM12 toolbox implemented in Matlab 2015b (MathWorks, Inc., Natick, MA) to derive voxel-wise gray matter volumes for each subject. The default settings of CAT12 were applied for spatial registration, normalization and segmentation of the T1weighted structural brain images. For a precise spatial normalization into standard (MNI), the Diffeomorphic Anatomic Registration Through Exponentiated Linear algebra algorithm (DARTEL) (Klein et al., 2009) was performed. The images were segmented into gray matter, white matter, and cerebrospinal fluid, and modulated with Jacobian determinants. Finally, the modulated gray matter images were smoothed with an $8 \mathrm{~mm}$ isotropic 
medRxiv preprint doi: https://doi.org/10.1101/2020.07.21.20158634; this version posted July 22, 2020. The copyright holder for this preprint (which was not certified by peer review) is the author/funder, who has granted medRxiv a license to display the preprint in perpetuity.

It is made available under a CC-BY-NC-ND 4.0 International license.

1 FWHM Gaussian kernel. Subsequently, the association between brain structure and clinical indicators of patients experiencing RLS in pregnancy was systematically charted.

\section{Assessing the clinical and anamnestic indicators in predicting RLS}

Independent samples t-tests (for continuous variables) and chi-square tests (for categorical variables) were used to assess differences between the RLS and control groups. Within-group differences were analyzed by means of paired samples t-tests, with IBM Statistics 25 (SPSS, Chicago, IL) being used for the analysis.

The relative importance of the clinical and anamnestic indicators for predicting RLS was analyzed using a L2penalized logistic regression based on the information of 57 RLS patients and 26 matched healthy controls.

10 The L2 regularization was used to reduce the chances of overfitting, which can render the models' prediction 11 of future observation unreliable (Okser et al., 2014). The L2-penalized logistic regression estimated the 12 separating hyperplane (i.e., a linear function), distinguishing between patients with RLS and healthy 13 participants. The outcome to be predicted was defined by being healthy (0) or being a patient with RLS (1). 14 The model parameters were then fit to optimally predict RLS based on all the standardized clinical and anamnestic data.

\section{Brain-phenotype association across the whole-brain gray matter}

The relationship between brain structure and clinical and anamnestic indicators of patients experiencing restless legs syndrome (RLS) in pregnancy was systematically charted based on the structural magnetic resonance imaging (T1-MRI) data from RLS patients in pregnancy.

\section{Signal extraction}

Using the Automated Anatomical Labeling (AAL) ROI atlas (Tzourio-Mazoyer et al., 2002), quantitative measures of gray matter volume were extracted within the 116 macroscopic brain structures labeled in this atlas in every patient. Widely used in neuroimaging (Fransson and Marrelec, 2008; Rubinov, 2013; Yang et al., 2013), the AAL atlas is the result of an automated anatomical parcellation of the spatially normalized singlesubject high-resolution scan of the brain.

For the extraction of relevant signal from the structural brain data, the total of 116 regions served as topographic masks to average the volume information across the voxels belonging to a given region. Each AAL region was represented by the average gray matter volume across all AAL region voxels. This way of engineering the 
medRxiv preprint doi: https://doi.org/10.1101/2020.07.21.20158634; this version posted July 22, 2020. The copyright holder for this preprint (which was not certified by peer review) is the author/funder, who has granted medRxiv a license to display the preprint in perpetuity.

It is made available under a CC-BY-NC-ND 4.0 International license.

morphological brain features yielded as many volumetric brain variables per patient as the total number of AAL regions (i.e., 116). All region-wise structural volumes were transformed into z-scores by mean centering and unit-variance scaling (Gelman and Hill, 2006).

\section{Joint multivariate decomposition across the whole brain}

A multivariate pattern analysis technique, namely the canonical correlation analysis (CCA), was employed (Wang et al., 2020). This approach relates multiple blocks of data (with structural imaging features on the one hand, and anamnestic and clinical indicators on the other) through a latent factor model. Projections of the first 10 principal components of the standardized volumetric brain measures (i.e., $25 * 10$ matrix) as well as the

10 first 10 principal component projections of the standardized anamnestic/clinical data (i.e., $25 * 10$ matrix) were 11 fed into a CCA algorithm, the number 25 indicating the number of subjects included in the analysis. This 12 multivariate and multimodality approach enabled us to objectively assess the relationship between patient 13 differences in brain volume and anamnestic/clinical indicators. The CCA determines the canonical vectors $\mathrm{u}$ 14 and $\mathrm{v}$ that maximize the symmetric relationship between a linear combination of brain volumes $(\mathrm{X})$ and a linear combination of anamnestic and clinical data $(\mathrm{Y})$, thereby identifying the two projections, $\mathrm{Xu}$ and $\mathrm{Yv}$, that yield maximal linear co-occurrence between sets of regions with volumetric changes and sets of patients' clinical changes. In concrete terms, the positive (negative) modulation weights revealed increased (decreased) strengths of brain-behavior association relative to the baseline volumetric changes.

In sum, using the CCA, which finds linear combinations to optimize correlations between brain region volumes and an array of anamnestic/clinical measures, we estimated pairs of canonical variates along which sets of anamnestic/clinical measures and patterns of brain volume correlated coherently across subjects. Henceforth, we refer to each pair of such variates as a 'mode' of coherent brain-phenotype co-variation.

Testing for statistically significant brain-behavior associations between brain volume and phenotypical indicators

Following the CCA of RLS patients, the statistical robustness of the ensuing brain-phenotype relationship was assessed through a non-parametric permutation approach (Efron, 2012; Nichols and Holmes, 2002) using the canonical correlation as the test statistic. Relying on minimal modeling assumptions, a valid null distribution was derived for the achieved correlation between the canonical variates resulting from the CCA analysis. In 1,000 permutation iterations, the brain volume matrix was held constant, while the anamnestic and clinical data matrix underwent patient-wise random shuffling. While the constructed surrogate data preserved the statistical structure idiosyncratic to the MRI-derived signals, they were permitted to selectively destroy the signal property related to the CCA statistic to be tested (Wang et al., 2020). The empirical distribution thus generated reflected the null hypothesis of random association between volume and anamnestic and clinical indicators across patients. The Pearson correlation $r$ between the perturbed canonical variates were recorded 
medRxiv preprint doi: https://doi.org/10.1101/2020.07.21.20158634; this version posted July 22, 2020. The copyright holder for this preprint (which was not certified by peer review) is the author/funder, who has granted medRxiv a license to display the preprint in perpetuity.

It is made available under a CC-BY-NC-ND 4.0 International license .

1 in each iteration, with the P-values being obtained from the number of correlations $r$ from the null CCA model.

2 This analysis revealed a single significant CCA mode that relates brain volume to subjects' clinical and

3 anamnestic measures $(\mathrm{p}<0.05)$.

\section{Post-hoc brain-phenotype association of the basal ganglia}

6 With the whole-brain results showing the basal ganglia to be the site of the most important and inter7 hemispheric variations across brain volumes, we further investigated patterns of changes in the basal ganglia 8 specifically related to the anamnestic and clinical indicators. Quantitative measures of gray matter volume 9 were extracted within the basal ganglia brain structures, the left and right caudate and putamen, as labeled in 10 AAL in every participant. This way of engineering morphological brain features yielded as many volumetric 11 brain variables per patient as the total number of voxels included in these AAL regions (i.e., 10881). All region12 wise structural volumes were transformed into z-scores by mean centering and unit-variance scaling. The first 1310 principal components of the standardized basal ganglia volumetric brain measures as well as the first 10 14 principal components of the standardized clinical and anamnestic data were fed into a CCA. Following the 15 preceding whole-brain CCA (cf. previous paragraph), only the first mode was automatically computed.

\section{Code availability}

18 Python was selected as the scientific computing engine, the open-source ecosystem of which helps enhance 19 replicability, reusability and provenance tracking. Scikit-learn (Pedregosa et al., 2011) provided efficient, unit20 tested implementations of state-of-the-art statistical learning algorithms (http://scikit-learn.org). All analysis 21 scripts of the present study are readily accessible to the reader online 22 (https://github.com/JLefortBesnard/RLS_2019). 
medRxiv preprint doi: https://doi.org/10.1101/2020.07.21.20158634; this version posted July 22, 2020. The copyright holder for this preprint (which was not certified by peer review) is the author/funder, who has granted medRxiv a license to display the preprint in perpetuity. It is made available under a CC-BY-NC-ND 4.0 International license .

\section{RESULTS}

\section{Course of RLS in pregnancy}

57 (19\%) of the 308 women reported to experience RLS symptoms during pregnancy. While for 22 (39\%) of them this was the first pregnancy, for 35 (61\%), it was a second or third pregnancy. Of these 35 women, 20 (57\%) had experienced RLS symptoms during a previous pregnancy. 19 (33\%) of the 57 women continued to experience RLS symptoms 12 weeks after delivery. However, the severity of RLS symptoms 12 weeks after delivery ( $\mathrm{T} 1)(\mathrm{M}=15.68, \mathrm{SD}=7.22)$ was significantly lower compared to the severity of RLS symptoms at $\mathrm{T} 0(\mathrm{M}=18.95, \mathrm{SD}=5.54), \mathrm{t}(18)=3.314, \mathrm{p}=0.04$. For $2(4 \%)$ women, no information was available with respect to RLS symptoms 12 weeks postpartum. 38 women (67\%) reported the RLS symptoms to have been most severe during the third trimester of pregnancy (for details, see Table 1A).

\section{Differences between RLS and control groups}

Participants with RLS symptoms during pregnancy were older $(\mathrm{Mdn}=35)$ compared to their counterparts without RLS $(\mathrm{Mdn}=31), \mathrm{U}=8.688, \mathrm{p}=0.11$. Also, women in the RLS group had more often gestational diabetes $(n=10,17.5 \%)$ compared to those in the control group without RLS $(n=29,11.6 \%), \chi^{2}(1,308)=$ $6.040, \mathrm{p}=.049$. In addition, a significantly larger number of women in the RLS group $(\mathrm{n}=35,61.4 \%)$ experienced SLE compared to the control group $(n=103,41.4 \%), \chi^{2}(1,306)=7.522, p=.006$ and were not married, $\chi^{2}(1,307)=3.941,=.047$ (see Table 1B). On the other hand, the groups with and without RLS did not differ with respect to depressivity (EPDS) and HCC at any time point and Hemoglobin in g/dL at T0, and also in terms of severity of baby blues, birth mode, multiparity and psychiatric history.

\section{Detecting behavioral descriptors that distinguish patients with RLS}

In a group of 57 RLS patients and 26 matched healthy controls, we explored the contribution of each anamnestic and clinical indicator to the detection of patients with RLS. Eight out of 28 variables were highly weighted for detecting patients with RLS. In addition to the total and IRLSS, further features indicative of RLS included experience of RLS in a previous pregnancy, and a high score with respect to the questions 1, 2, 3, 6 , 7 and 8 (Fig. 1, Tab.1C). Here, the items describing the degree of RLS symptom relief by exercise (Q3), the urge to move the legs (Q2) and the average severity of the unpleasant sensations in the legs (Q8) were most indicative of patients with RLS. On the other hand, items describing the degree of sleep disturbance (Q4, Q5) as well as being affected in the daily activities (Q9) or mood disturbances (Q10) were the least indicative. Age, number of children, duration of pregnancy, birthweight or mode of birth also did not contribute to the detection of participants affected by pregnancy-related RLS. 
medRxiv preprint doi: https://doi.org/10.1101/2020.07.21.20158634; this version posted July 22, 2020. The copyright holder for this preprint (which was not certified by peer review) is the author/funder, who has granted medRxiv a license to display the preprint in perpetuity. It is made available under a CC-BY-NC-ND 4.0 International license .

The main objective of the whole-brain study was to identify components of the relationship between brain structures and clinical traits that described RLS patients in pregnancy. A single statistically significant CCA mode emerged in the first analysis $(r=0.993, p<0.05)$, exhibiting a strong covariation of brain volume measures and diverse anamnestic and clinical indicators (Figure 2, Table 2). The other 9 of the 10 estimated modes were not significantly robust. The most important CCA mode comprised measures that varied along a positive-negative axis. As regards the anamnestic and clinical indicators, a high cortisol level, being married, and receiving iron supplements were located at the positive end of the mode. The brain regions at the positive end of the mode included the left superior temporal pole, the left inferior frontal gyrus, the basal ganglia (right and left caudate nucleus and putamen), and the right lobule 6 of the cerebellar hemisphere. Note that only the basal ganglia changes were located in both hemispheres. The most significant anamnestic and clinical changes located at the negative end of the mode included positive history of RLS in previous pregnancy, not being married and not receiving any iron supplement. Further anamnestic and clinical changes located at the negative end of the mode included complaining about the severity of RLS-related sensations (Q1), the degree of the urge to move the legs (Q2), and the number of SLE. Brain regions with high negative loadings included the right inferior parietal lobule, the left posterior cingulate gyrus, the right lobule 9, VIIIb, crus II and the left lobule 10 of the cerebellar hemisphere, the left olfactory cortex, the left superior frontal gyrus, the right postcentral gyrus, the left and right calcarine sulci and the right medial orbitofrontal cortex. In sum, our results identified several inter-hemispheric zones of activity, especially in the basal ganglia, contributing to coherent anamnestic and clinical changes. Based on this observation, we focused on this particular region in a second analysis.

\section{Second CCA analysis: exploratory voxel-level investigation within the basal ganglia}

As a logical follow-up, we studied the relationship between changes in the phenotypical predictors and specific changes within the basal ganglia in RLS patients in pregnancy (Figure 3, Table 2). To that end, the first 10 principal components of standardized brain volume of the basal ganglia regions and the first 10 principal components of standardized anamnestic and clinical data were fed into the CCA, with only one CCA mode being computed given the previous results. The anamnestic and clinical changes located at the positive end of the mode included having a heavier baby and having the unpleasant sensations in the legs or arms alleviated by exercise (Q3), while the basal ganglia changes at the positive end of the mode were the left and right body and head of the caudate nucleus and the left and right inferior putamen. The amnestic and clinical changes at the negative end of the mode were being young and not being so affected by RLS on a daily basis (Q9), while the corresponding brain volume changes included the superior part of the putamen. caudate and the inferior part of the putamen as the size of the baby and RLS-related sleep deprivation increased. 
medRxiv preprint doi: https://doi.org/10.1101/2020.07.21.20158634; this version posted July 22, 2020. The copyright holder for this preprint (which was not certified by peer review) is the author/funder, who has granted medRxiv a license to display the preprint in perpetuity. It is made available under a CC-BY-NC-ND 4.0 International license.

\section{DISCUSSION}

In a large neurological-obstetrical sample of 308 postpartum women, participants with pregnancy-related RLS were identified and compared with the rest of the sample. Furthermore, a number of clinical and anamnestic indicators of RLS in pregnancy were assessed by leveraging state-of-the-art machine learning algorithms. Within the group of women with pregnancy-related RLS, the phenotypical predictors of the condition were assessed by means of a brain structure analysis of the brain phenotype model.

The RLS prevalence rate in our sample was found to be $19 \%$. While in $30 \%$ of the cases the symptoms were still reported 12 weeks postpartum, 70\% of the women experienced a complete recovery of RLS symptoms shortly after delivery. The majority of participants experienced the RLS symptoms as most severe and most frequent in the last trimester of pregnancy. In line with previous findings (Innes et al., 2015; Ramirez et al., 2013), those afflicted by RLS in our sample were older and more often affected by gestational diabetes than their unaffected counterparts. We found also that women experiencing RLS in pregnancy reported to experience SLE more often than those without RLS (Chandan et al., 2019). Additionally, there were group differences in terms of marital status, with women in the RLS group being more often not married.

Examining the possible predictive factors of RLS in pregnancy, we found a history of RLS to be the strongest predictor of the condition in current pregnancy, which is in line with previous reports (Cesnik et al., 2010). In IRLSS, items describing the degree of urge to move the legs and the degree of RLS symptom relief afterword were better predictors of pregnancy-related RLS symptoms compared to those describing daily activity, mood or sleep.

As regards the relationship between whole-brain gray matter morphology and phenotypical predictors, high HCC, being married and receiving iron supplements were found to be associated with increased volumes of the left superior temporal pole, the left inferior frontal gyrus and the basal ganglia (the right and left caudate nucleus and putamen). Previous studies have foreshadowed a possible physiological link between factors such as the circadian rhythm of cortisol secretion or iron deficiencies in the central nervous system (CNS) and manifestation of idiopathic RLS. In particular, an evening and early night hour RLS symptom increase has been suggested to be moderated by low-dose hydrocortisone (Hornyak et al., 2008; Rizzo and Plazzi, 2018). Apart from the circadian rhythm of cortisol secretion, reduction of brain iron is thought to be one of the risk factors in the development of RLS symptoms (Rizzo and Plazzi, 2018), the iron deficiency being attributed to dysregulations in the dopamine system (Earley et al., 2014). Also noteworthy is the relationship seen between marital status and increased basal ganglia structures in RLS patients. Married individuals are suggested to be healthier (Robards et al. 2012; Svetel et al. 2015) and therefore less likely to be exposed to stressors compared to those who either never married or were previously married (Chin et al., 2017). As also suggested by previous research, the positive relationship between brain volume in the striatum and frontal areas and such factors as higher HCC, iron supplementation or being married are likely associated with more favorable prognoses with respect to pregnancy-related RLS. At the same time, a history of RLS, not being married and not receiving any 
medRxiv preprint doi: https://doi.org/10.1101/2020.07.21.20158634; this version posted July 22, 2020. The copyright holder for this preprint (which was not certified by peer review) is the author/funder, who has granted medRxiv a license to display the preprint in perpetuity. It is made available under a CC-BY-NC-ND 4.0 International license .

iron supplement were found to be associated with a decreased volume size of the (right inferior) parietal lobule, the posterior cingulate, and the right medial orbitofrontal and frontal (left superior frontal gyrus) cortices. The same negative relationship of brain volume in the above-mentioned regions was seen with the severity of RLSrelated sensations, the intensity of the urge to move the legs and the number of SLE. Based on these observations, we suggest that the association between reduced brain volume and factors such as history of RLS, not being married, higher number of SLE or being more strongly affected by RLS symptoms is probably indicative of a less favorable prognosis for pregnancy-related RLS. This assumption is supported by the fact that a history of RLS and the intensity of the urge to move the legs were found to be the strongest predictors of pregnancy-related RLS symptoms in our sample. Previous research has indicated links between SLE such as child maltreatment and the development of a set of somatic and visceral central sensitivity syndromes like chronic pain, irritable bowel syndrome as well as RLS (Chandan et al., 2019).

Taken together, our results suggest that pregnancy-related RLS (similarly to idiopathic RLS (Margariti et al., 2012; Rizzo and Plazzi, 2018)) is linked to the striatal and frontoparietal structures. As the whole-brain results of our study show, the most important and interhemispheric variations occur in the basal ganglia, with the medial and lateral striata contributing the most to the clinical and anamnestic differences in the pregnancyrelated RLS group. Along with our results, the human lesion studies (Lee et al., 2009; Shiina et al., 2019; Woo et al., 2017) as well as the recent RLS animal model studies (Guo et al., 2017) underscore the crucial role of the basal ganglia in the manifestation of the RLS spectrum. Based on the brain phenotype model, we conclude therefore that different factors such as stress response, history of SLE or life circumstances (e.g. marital status) or iron deficiencies in the CNS contribute to the manifestation of RLS in pregnancy. Interconnected in a complex way, these factors, along with genetic predisposition, likely lead to the dysfunction of the mesolimbic and nigrostriatal dopaminergic pathways, triggering abnormalities in the limbic/nociceptive and sensorimotor networks (Rizzo and Plazzi, 2018) and the development of RLS symptoms. The investigation of RLS in pregnancy in a brain phenotype model has the potential of helping augment our understanding of the heterogeneity of the spectrum.

\section{Acknowledgments}

This study was funded by the rotation program of the medical faculty of University Hospital RWTH Aachen and the Deutsche Forschungsgemeinschaft (DFG, CH 1718/2-1) and was supported by the International Research Training Group (IRTG 2150) of the German Research Foundation (DFG).

DB was supported by the Healthy Brains Healthy Lives initiative (Canada First Research Excellence fund), Google (Research Award), and by the CIFAR Artificial Intelligence Chairs program (Canada Institute for Advanced Research).

\section{Author Contribution}

34 Conceptualization, N.C., D.B. and T.G; Methodology, D.B.; Software, D.B.; Validation, D.B., N.C. and J.L.; 35 Formal Analysis, J.L. and N.C; Investigation, M.F., S.S, P.S, and T.G; Resources, N.C. and T.G; Data Curation, 
medRxiv preprint doi: https://doi.org/10.1101/2020.07.21.20158634; this version posted July 22, 2020. The copyright holder for this preprint (which was not certified by peer review) is the author/funder, who has granted medRxiv a license to display the preprint in perpetuity. It is made available under a CC-BY-NC-ND 4.0 International license.

S.S., and P.S.; Writing - Original Draft Preparation, N.C.; Writing - Review \& Editing, N.C., JL., TG., MF., P.S., S.S, and DB; Visualization, J.L.; Supervision, D.B.; Project Administration, M.F.; Funding Acquisition, 3 N.C.

\section{Conflict of interest}

The authors declare no conflicts of interest.

\section{Bibliography}

Allen, R.P., Picchietti, D.L., Garcia-Borreguero, D., Ondo, W.G., Walters, A.S., Winkelman, J.W., Zucconi, M., Ferri, R., Trenkwalder, C., Lee, H.B., 2014. Restless legs syndrome/Willis-Ekbom disease

Berger, K., Luedemann, J., Trenkwalder, C., John, U., Kessler, C., 2004. Sex and the risk of restless legs syndrome in the general population. Arch. Intern. Med. 164, 196. doi:10.1001/archinte.164.2.196

Castillo, P.R., Mera, R.M., Fredrickson, P.A., Zambrano, M., Del Brutto, V.J., Del Brutto, O.H., 2014. Psychological distress in patients with restless legs syndrome (Willis-Ekbom disease): A population-

Cesnik, E., Casetta, I., Turri, M., Govoni, V., Granieri, E., Ferini Strambi, L., Manconi, M., 2010. Transient RLS during pregnancy is a risk factor for the chronic idiopathic form. Neurology 75, 2117-2120. doi:10.1212/WNL.0b013e318200d779

Cox, J.L., Holden, J.M., Sagovsky, R., 1987. Detection of postnatal depression: development of the 10-item brain. Front. Neuroendocrinol. doi:10.1016/j.yfrne.2019.02.004 
medRxiv preprint doi: https://doi.org/10.1101/2020.07.21.20158634; this version posted July 22, 2020. The copyright holder for this preprint (which was not certified by peer review) is the author/funder, who has granted medRxiv a license to display the preprint in perpetuity. It is made available under a CC-BY-NC-ND 4.0 International license .

Earley, C.J., Connor, J., Garcia-Borreguero, D., Jenner, P., Winkelman, J., Zee, P.C., Allen, R., 2014. Altered Brain iron homeostasis and dopaminergic function in Restless Legs Syndrome (Willis-Ekbom Disease).

Fransson, P., Marrelec, G., 2008. The precuneus/posterior cingulate cortex plays a pivotal role in the default

Gelman, A., Hill, J., 2006. Data analysis using regression and multilevel/hierarchical models, Data Analysis mode network: Evidence from a partial correlation network analysis. Neuroimage 42, 1178-1184. doi:10.1016/j.neuroimage.2008.05.059

Gao, X., Schwarzschild, M.A., Wang, H., Ascherio, A., 2009. Obesity and restless legs syndrome in men and women. Neurology 72, 1255-1261. doi:10.1212/01.wnl.0000345673.35676.1c Using Regression and Multilevel/Hierarchical Models. Cambridge University Press. doi:10.1017/cbo9780511790942

Goodman, L.A., Corcoran, C., Turner, K., Yuan, N., Green, B.L., 1998. Assessing traumatic event exposure: General issues and preliminary findings for the Stressful Life Events Screening Questionnaire. J. Trauma. Stress Off. Publ. Int. Soc. Trauma. Stress Stud. 11, 521-542.

Guo, C.-N., Yang, W.-J., Zhan, S.-Q., Yang, X.-F., Chen, M.C., Fuller, P.M., Lu, J., 2017. Targeted disruption of supraspinal motor circuitry reveals a distributed network underlying restless legs syndrome (RLS)like movements in the rat. Sci. Rep. 7, 9905.

Gupta, R., Dhyani, M., Kendzerska, T., Pandi-Perumal, S.R., Bahammam, A.S., Srivanitchapoom, P., Pandey, S., Hallett, M., 2016. Restless legs syndrome and pregnancy: Prevalence, possible pathophysiological mechanisms and treatment. Acta Neurol. Scand. doi:10.1111/ane.12520

Haider, B.A., Olofin, I., Wang, M., Spiegelman, D., Ezzati, M., Fawzi, W.W., Group, N.I.M.S., 2013. Anaemia, prenatal iron use, and risk of adverse pregnancy outcomes: systematic review and metaanalysis.

Horiguchi, J., Hornyak, M., Voderholzer, U., Kryger, M., Skomrow, R., Lipinski, J.F., Masood, A., Phillips, B., Oertel, W.H., Stiasny, K., O’Keeffe, S., Oldani, A., Zucconi, M., Ondo, W.G., Picchietti, D., Poceta, J.S., Rich, G.B., Scrima, L., Shafor, R., Sharon, D., Silber, M., Smith, R., Trenkwalder, C., Wetter, T.C., Winkelmann, J., Vanek, Z., Wagner, M., Walters, A.S., 2003. Validation of the International Restless Legs Syndrome Study Group rating scale for restless legs syndrome. Sleep Med. 4, 121-132. doi:10.1016/S1389-9457(02)00258-7

Hornyak, M., Rupp, A., Riemann, D., Feige, B., Berger, M., Voderholzer, U., 2008. Low-dose hydrocortisone in the evening modulates symptom severity in restless legs syndrome. Neurology 70, 1620-1622. doi:10.1212/01.wnl.0000310984.45538.89 
medRxiv preprint doi: https://doi.org/10.1101/2020.07.21.20158634; this version posted July 22, 2020. The copyright holder for this preprint (which was not certified by peer review) is the author/funder, who has granted medRxiv a license to display the preprint in perpetuity. It is made available under a CC-BY-NC-ND 4.0 International license .

Innes, K.E., Kandati, S., Flack, K.L., Agarwal, P., Selfe, T.K., 2015. The association of restless legs syndrome to history of gestational diabetes in an appalachian primary care population. J. Clin. Sleep Med. 11, 1121-1130. doi:10.5664/jcsm.5084

Kallweit, U., Werth, E., Seiz, A., Sefidan, S., Dahmen, N., Manconi, M., Ehlert, U., Bassetti, C.L.A., 2016.

Klein, A., Andersson, J., Ardekani, B.A., Ashburner, J., Avants, B., Chiang, M.-C., Christensen, G.E.,

Ma, S., Shang, X., Guo, Y., Liu, G., Yang, J., Xue, R., 2015. Restless legs syndrome and hypertension in Collins, D.L., Gee, J., Hellier, P., 2009. Evaluation of 14 nonlinear deformation algorithms applied to human brain MRI registration. Neuroimage 46, 786-802.

Lee, S., Kim, J., Song, I., An, J., Kim, Y., Lee, K., 2009. Poststroke restless legs syndrome and lesion location: anatomical considerations. Mov. Disord. 24, 77-84. Chinese pregnant women. Neurol. Sci. 36, 877-881. doi:10.1007/s10072-015-2094-4

Margariti, P.N., Astrakas, L.G., Tsouli, S.G., Hadjigeorgiou, G.M., Konitsiotis, S., Argyropoulou, M.I., 2012. Investigation of unmedicated early onset restless legs syndrome by voxel-based morphometry, T2 relaxometry, and functional MR imaging during the night-time hours. Am. J. Neuroradiol. 33, 667-672. doi:10.3174/ajnr.A2829

Nichols, T.E., Holmes, A.P., 2002. Nonparametric permutation tests for functional neuroimaging: A primer with examples. Hum. Brain Mapp. 15, 1-25. doi:10.1002/hbm.1058

Ohayon, M.M., O'Hara, R., Vitiello, M. V., 2012. Epidemiology of restless legs syndrome: A synthesis of the literature. Sleep Med. Rev. doi:10.1016/j.smrv.2011.05.002

Ohayon, M.M., Roth, T., 2002. Prevalence of restless legs syndrome and periodic limb movement disorder in the general population. J. Psychosom. Res. 53, 547-554. doi:10.1016/S0022-3999(02)00443-9

Okser, S., Pahikkala, T., Airola, A., Salakoski, T., Ripatti, S., Aittokallio, T., 2014. Regularized machine learning in the genetic prediction of complex traits. PLoS Genet. 10, e1004754. doi:10.1371/journal.pgen.1004754

Pedregosa, F., Varoquaux, G., Gramfort, A., Michel, V., Thirion, B., Grisel, O., Blondel, M., Prettenhofer, P., Weiss, R., Dubourg, V., 2011. Scikit-learn: Machine learning in Python. J. Mach. Learn. Res. 12, 2825 2830.

Quinete, N., Bertram, J., Reska, M., Lang, J., Kraus, T., 2015. Highly selective and automated online SPE LC-MS3 method for determination of cortisol and cortisone in human hair as biomarker for stress related diseases. Talanta 134, 310-316. doi:10.1016/j.talanta.2014.11.034

Ramirez, J.O., Cabrera, S.A.S., Hidalgo, H., Cabrera, S.G., Linnebank, M., Bassetti, C.L., Kallweit, U., 2013. Is preeclampsia associated with restless legs syndrome? Sleep Med. 14, 894-896. doi:10.1016/j.sleep.2013.03.013 
medRxiv preprint doi: https://doi.org/10.1101/2020.07.21.20158634; this version posted July 22, 2020. The copyright holder for this preprint (which was not certified by peer review) is the author/funder, who has granted medRxiv a license to display the preprint in perpetuity. It is made available under a CC-BY-NC-ND 4.0 International license.

Rizzo, G., Plazzi, G., 2018. Neuroimaging applications in restless legs syndrome, in: International Review of Neurobiology. Academic Press Inc., pp. 31-64. doi:10.1016/bs.irn.2018.09.012

Robards, J., Evandrou, M., Falkingham, J., Vlachantoni, A., 2012. Marital status, health and mortality. Maturitas. doi:10.1016/j.maturitas.2012.08.007

Rubinov, M., 2013. Schizophrenia and abnormal brain network hubs. Dialogues Clin. Neurosci. 15, 339.

Shiina, T., Suzuki, K., Okamura, M., Matsubara, T., Hirata, K., 2019. Restless legs syndrome and its variants

Sonagra, A.D., Biradar, S.M., Dattatreya, K., DS, J.M., 2014. Normal pregnancy-a state of insulin resistance.

Srivanitchapoom, P., Pandey, S., Hallett, M., 2014. Restless legs syndrome and pregnancy: A review. Park.

Stalder, T., Kirschbaum, C., 2012. Analysis of cortisol in hair-state of the art and future directions. Brain.

Stalder, T., Steudte-Schmiedgen, S., Alexander, N., Klucken, T., Vater, A., Wichmann, S., Kirschbaum, C., Psychoneuroendocrinology. Elsevier Ltd. doi:10.1016/j.psyneuen.2016.12.017

Svetel, M. V., Jovic, J.S., Pekmezovic, T.D., Kostic, V.S., 2015. Quality of life in patients with primary restless leg syndrome: community-based study. Neurol. Sci. 36, 1345-1351. doi:10.1007/s10072-0152103-7

Trenkwalder, C., Allen, R., Högl, B., Paulus, W., Winkelmann, J., 2016. Restless legs syndrome associated with major diseases: a systematic review and new concept. Neurology 86, 1336-1343.

Tunç, T., Karadağ, Y.S., Doğulu, F., İnan, L.E., 2007. Predisposing factors of restless legs syndrome in pregnancy. Mov. Disord. 22, 627-631.

Tzourio-Mazoyer, N., Landeau, B., Papathanassiou, D., Crivello, F., Etard, O., Delcroix, N., Mazoyer, B., Joliot, M., 2002. Automated anatomical labeling of activations in SPM using a macroscopic anatomical parcellation of the MNI MRI single-subject brain. Neuroimage 15, 273-289.

Wang, H.T., Smallwood, J., Mourao-Miranda, J., Xia, C.H., Satterthwaite, T.D., Bassett, D.S., Bzdok, D., 2020. Finding the needle in a high-dimensional haystack: Canonical correlation analysis for neuroscientists. Neuroimage 216, 116745. doi:10.1016/j.neuroimage.2020.116745

Wesström, J., Skalkidou, A., Manconi, M., Fulda, S., Sundström-Poromaa, I., 2014. Pre-pregnancy restless legs syndrome (Willis-Ekbom Disease) is associated with perinatal depression. J. Clin. Sleep Med. 10, 527-533. doi:10.5664/jcsm.3704

Winkelmann, J., Schormair, B., Lichtner, P., Ripke, S., Xiong, L., Jalilzadeh, S., Fulda, S., Pütz, B., Eckstein, G., Hauk, S., 2007. Genome-wide association study of restless legs syndrome identifies common variants in three genomic regions. Nat. Genet. 39, 1000. 
medRxiv preprint doi: https://doi.org/10.1101/2020.07.21.20158634; this version posted July 22,2020 . The copyright holder for this preprint (which was not certified by peer review) is the author/funder, who has granted medRxiv a license to display the preprint in perpetuity.

It is made available under a CC-BY-NC-ND 4.0 International license .

1 Woo, H.G., Lee, D., Hwang, K.J., Ahn, T.-B., 2017. Post-stroke restless leg syndrome and periodic limb movements in sleep. Acta Neurol. Scand. 135, 204-210. doi:10.1111/ane.12582

3

Yang, A.C., Huang, C.-C., Yeh, H.-L., Liu, M.-E., Hong, C.-J., Tu, P.-C., Chen, J.-F., Huang, N.E., Peng, C.K., Lin, C.-P., 2013. Complexity of spontaneous BOLD activity in default mode network is correlated with cognitive function in normal male elderly: a multiscale entropy analysis. Neurobiol. Aging 34, $428-438$. 
medRxiv preprint doi: https://doi.org/10.1101/2020.07.21.20158634; this version posted July 22,2020 . The copyright holder for this preprint (which was not certified by peer review) is the author/funder, who has granted medRxiv a license to display the preprint in perpetuity.

It is made available under a CC-BY-NC-ND 4.0 International license .

\section{FIGURES}

Figure 1. Flowchart of inclusion into the study

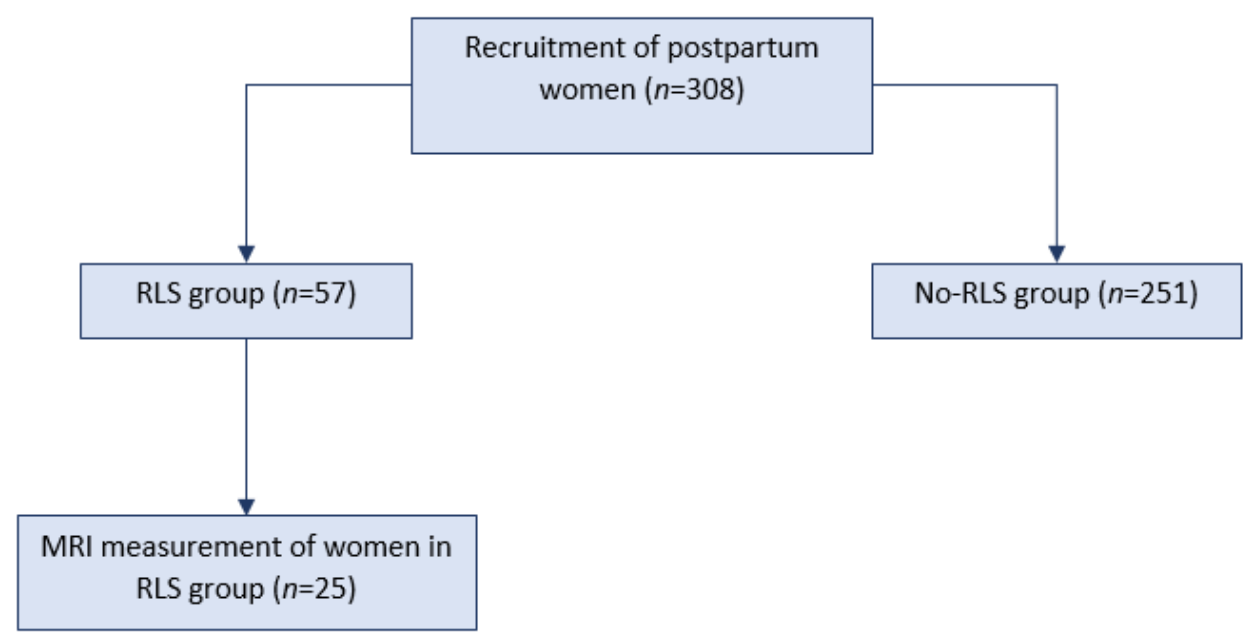


medRxiv preprint doi: https://doi.org/10.1101/2020.07.21.20158634; this version posted July 22, 2020. The copyright holder for this preprint (which was not certified by peer review) is the author/funder, who has granted medRxiv a license to display the preprint in perpetuity.

It is made available under a CC-BY-NC-ND 4.0 International license.

Figure 2. Informative features for predicting RLS

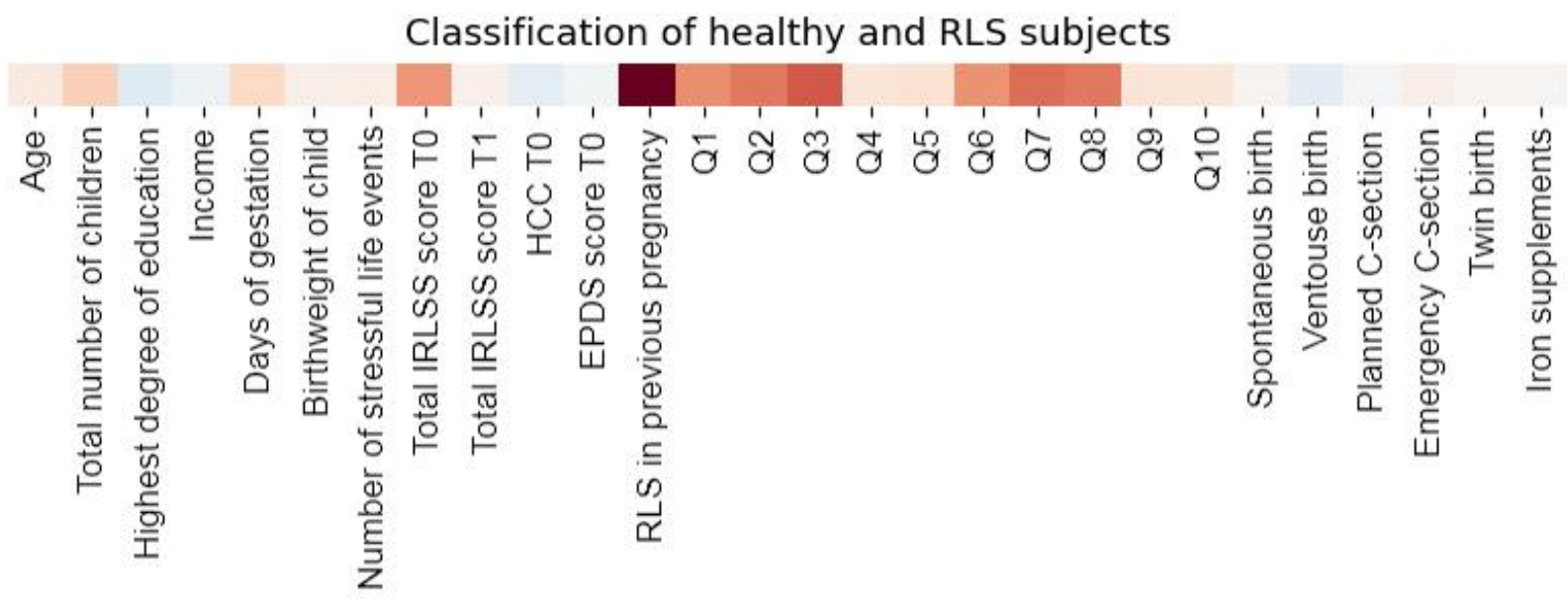

* IRLSS score T0 = Severity of RLS symptoms in pregnancy; IRLSS score T1 = Severity of RLS symptoms 12 weeks postpartum

A modern constrained version of logistic regression was deployed to explore the contribution of each anamnestic and clinical indicator to the prediction of RLS experience. The $\mathrm{x}$-axis depicts the variables included in the analysis. The red square indicates the feature contributing to the detection of an RLS patient while the blue square indicates the feature responsible for detecting a healthy participant. For example, a high score in the feature "RLS in previous pregnancy" would tip the balance of the output toward being an RLS patient, while a high level of cortisone (HCC T0) would tip the balance toward being a healthy participant. In sum, the most informative features with respect to the prediction of RLS were RLS in a previous pregnancy, and a high score against the questions $1,2,3,6,7$ and 8 . 
medRxiv preprint doi: https://doi.org/10.1101/2020.07.21.20158634; this version posted July 22, 2020. The copyright holder for this preprint (which was not certified by peer review) is the author/funder, who has granted medRxiv a license to display the preprint in perpetuity.

It is made available under a CC-BY-NC-ND 4.0 International license .

Figure 3. CCA reveals multivariate patterns of link between phenotypical predictors of RLS and brain structure

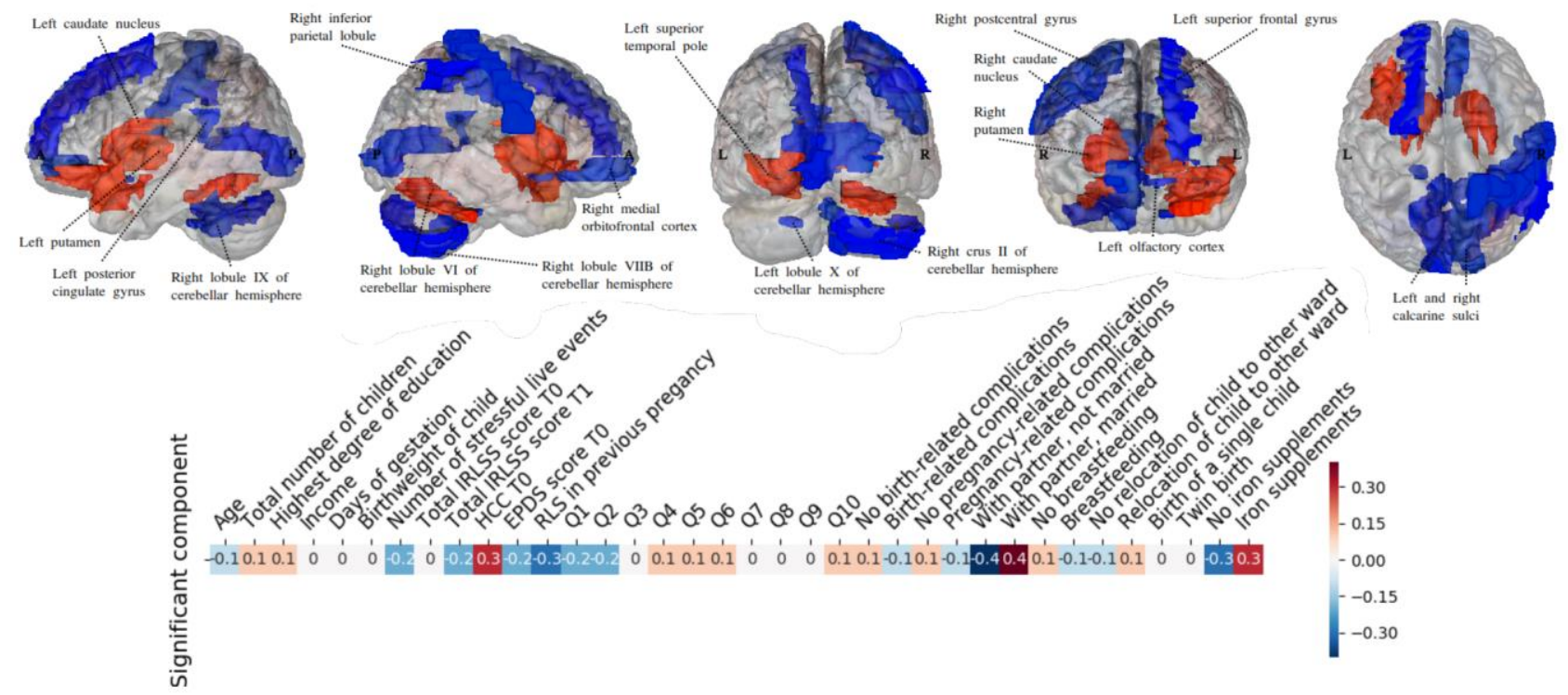

* IRLSS score T0 = Severity of RLS symptoms in pregnancy; IRLSS score T1 = Severity of RLS symptoms 12 weeks postpartum

The figure shows the first canonical model of brain-behavior co-variation that was statistically significant based on permutation testing $(\mathrm{p}<0.05)$. In the top row, the brain structure loadings are plotted from the left, right, posterior, anterior and superior views. The blue regions indicate the negative CCA loading associated with volume in this specific region, while the red region volumes indicate a positive CCA loading for this specific region. The bottom row depicts the loadings of the patient's anamnestic and clinical indicators (blue for a negative loading and red for a positive one). A high cortisol level, being married, and receiving iron supplement were robustly linked to an increased size of the left superior temporal pole, the left inferior frontal gyrus, the basal ganglia (right and left caudal nucleus and putamen), and the right lobule 6 of the cerebellar hemisphere. On the other hand, RLS during previous pregnancy (positive history of RLS), not being married and not receiving any iron supplement were found to be linked to a decreased volume size of the right inferior parietal lobule, the left posterior cingulate gyrus, the right lobule $9,8 \mathrm{~B}$, crus 2 and the left lobule 10 of the cerebellar hemisphere, the left olfactory cortex, the left superior frontal gyrus, the right postcentral gyrus, the left and right calcarine sulci and the right medial orbitofrontal cortex. Further anamnestic and clinical changes located at the negative end of the mode included complaining about the severity of RLS-related sensations (Q1), the degree of the urge to move the legs (Q2), and the number of SLE. That the most inter-hemispherically coherent brain-phenotype associations were found in the basal ganglia justified our targeted analysis (Fig. 2) 
medRxiv preprint doi: https://doi.org/10.1101/2020.07.21.20158634; this version posted July 22, 2020. The copyright holder for this preprint (which was not certified by peer review) is the author/funder, who has granted medRxiv a license to display the preprint in perpetuity.

It is made available under a CC-BY-NC-ND 4.0 International license.

Figure 3. Specific patterns linking the basal ganglia to the phenotypical predictors of RLS

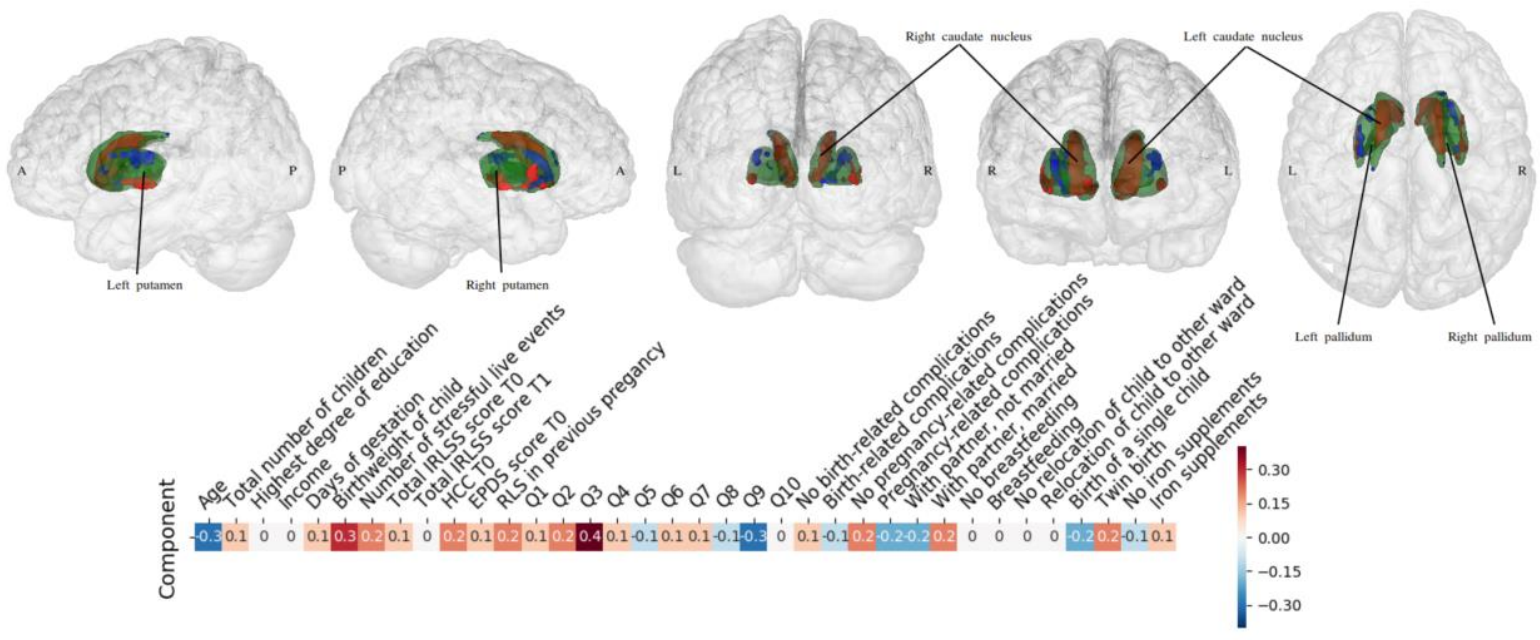

* IRLSS score T0 = Severity of RLS symptoms in pregnancy; IRLSS score T1 = Severity of RLS symptoms 12 weeks postpartum

A targeted post-hoc CCA was applied to find coherent associations between the basal ganglia volume changes and changes in the patients' anamnestic and clinical indicators. While the above-mentioned analysis (Fig. 2) considered the whole brain as measured by volume estimates, the present analysis focused on the left and right basal ganglia at a more fine-grained voxel resolution. Green indicates the anatomy of the target regions as part of the basal ganglia. In the top row, the loadings of the basal ganglia voxels are plotted from the left, right, posterior, anterior and superior views. The green area contours expose the outer shape of the basal ganglia voxels, which cover the striatum (putamen and caudate nucleus) and the pallidum. Within the basal ganglia, the blue area indicates negative CCA loadings associated with those specific voxels while the red indicates positive CCA loadings for those specific voxels. The bottom row depicts the loadings of the patient's behavioral and clinical indicators (blue for negative and red for positive). While having a baby with higher birth weight and having the unpleasant sensations in the legs or arms alleviated by exercise (Q3) were strongly linked to an increased size of the body and head of the left and right caudate nuclei and the left and right inferior putamen, being young and not being so affected by RLS (Q9) were found to be associated with a decreased size of the superior part of the left and right putamen. In sum, our analysis revealed strong associations between anamnestic changes and changes in the medial and lateral striatum within the basal ganglia. 
medRxiv preprint doi: https://doi.org/10.1101/2020.07.21.20158634; this version posted July 22, 2020. The copyright holder for this preprint (which was not certified by peer review) is the author/funder, who has granted medRxiv a license to display the preprint in perpetuity.

Table 1A Demographics of the whole sample

\begin{tabular}{|c|c|c|c|c|c|}
\hline & $n(\%)$ & M (SD) & Md & $\begin{array}{l}\text { Measured } \\
\text { study range }\end{array}$ & $\begin{array}{l}\text { Scale/ Method } \\
\text { range }\end{array}$ \\
\hline Age & $308(100)$ & $31.78(4.66)$ & 32 & $19-46$ & \\
\hline Married & $\begin{array}{r}226 \\
(73.4)\end{array}$ & & & & \\
\hline Unmarried & $81(26.3)$ & & & & \\
\hline Single parent & 8 (2.6) & & & & \\
\hline \multicolumn{6}{|l|}{ Number of children } \\
\hline 1 & $\begin{array}{r}163 \\
(52.9)\end{array}$ & & & & \\
\hline 2 & $\begin{array}{r}107 \\
(34.7)\end{array}$ & & & & \\
\hline 3 & $28(9.1)$ & & & & \\
\hline 4 & $6(1.9)$ & & & & \\
\hline 5 & $2(0.6)$ & & & & \\
\hline \multicolumn{6}{|l|}{ Highest education } \\
\hline No school graduation & $3(1.0)$ & & & & \\
\hline Secondary school degree & $11(3.6)$ & & & & \\
\hline Junior high school degree & $43(14.0)$ & & & & \\
\hline University entrance & $\begin{array}{r}146 \\
(47.4) \\
\end{array}$ & & & & \\
\hline \multicolumn{6}{|l|}{ Diploma } \\
\hline College degree & $77(25.0)$ & & & & \\
\hline Doctoral degree & $20(6.5)$ & & & & \\
\hline \multicolumn{6}{|l|}{ Birth mode } \\
\hline Spontaneous & $\begin{array}{r}173 \\
(56.2) \\
\end{array}$ & & & & \\
\hline Ventouse & $19(6.2)$ & & & & \\
\hline Planned C-section & $78(25.3)$ & & & & \\
\hline Emergency C-section & $38(12.3)$ & & & & \\
\hline Twin birth & $7(2.2)$ & & & & \\
\hline \multicolumn{6}{|l|}{$\begin{array}{l}\text { Pregnancy-related } \\
\text { complications }\end{array}$} \\
\hline $\begin{array}{l}\text { Pre-eclampsia/ } \\
\text { Hypertension }\end{array}$ & $18(5.8)$ & & & & \\
\hline Gestational Diabetes & $39(12.7)$ & & & & \\
\hline $\begin{array}{l}\text { Restless Legs Syndrome } \\
\text { (RLS) T0 }\end{array}$ & $57(18.5)$ & & & & \\
\hline $\begin{array}{r}\text { Severity of RLS symptoms } \\
\text { in pregnancy (IRLSS score T0) }\end{array}$ & & $18.95(5.54)$ & & $5-36$ & $0-40$ \\
\hline $\begin{array}{l}\text { Restless Legs Syndrome } \\
\text { (RLS) T1 }\end{array}$ & $19(6.0)$ & & & & \\
\hline $\begin{array}{l}\text { Severity of RLS symptoms } \\
12 \text { weeks postpartum (IRLSS } \\
\text { score T1) }\end{array}$ & & $15.68(7.22)$ & & $0-29$ & $0-40$ \\
\hline RLS in previous pregnancy & $20(6.5)$ & & & & \\
\hline Birth weight of child & & $3324.45(559.68)$ & 3350 & $840-5350$ & \\
\hline Days of gestation & & 272.65 & 275 & & \\
\hline Breastfeeding T0 & $\begin{array}{r}270 \\
(87.7)\end{array}$ & & & & \\
\hline $\begin{array}{l}\text { Stressful Life Events } \\
\text { (SLESQ) }\end{array}$ & $73(44.2)$ & $0.89(0.33)$ & 0 & $0-7$ & $0-13$ \\
\hline
\end{tabular}


medRxiv preprint doi: https://doi.org/10.1101/2020.07.21.20158634; this version posted July 22,2020 . The copyright holder for this preprint (which was not certified by peer review) is the author/funder, who has granted medRxiv a license to display the preprint in perpetuity.

It is made available under a CC-BY-NC-ND 4.0 International license .

\begin{tabular}{lcccr|}
\hline Psychiatric history & $52(16.8)$ & & & \\
\hline Depression Score T0 (EPDS) & $4.96(3.62)$ & 5 & $0-22$ & $0-30$ \\
\hline Depression Score T1 (EPDS) & $3.96(3.89)$ & 3 & $0-22$ & $0-30$ \\
\hline HCC T0 (pg/mg) & 9.75 & 5.31 & $0.71-91.55$ & $2.2-72.2^{2}$ \\
\hline HCC T1 (pg/mg) & $12.18(86.09)$ & & $0.33-1468.22$ & $2.2-72.2^{2}$ \\
\hline Hemoglobin T0 & 11.958 & 12 & $7.70-14.60$ & $11.2-15.7$ \\
\hline
\end{tabular}

Notes: $n=$ absolute frequency, $\%=$ relative frequency, $\mathrm{M}=$ mean, $\mathrm{SD}=$ standard deviation, $\mathrm{Md}=$ median,

IRLSS= International Restless Legs Syndrome Scale, SLESQ= Stressful Life Events Screening

Questionnaire; EPDS= Edinburgh Postnatal Depression Scale, $\mathrm{HCC}=$ hair cortisol concentration, $\mathrm{T} 0=$

baseline measure in childbed

${ }^{1}$ Reported range of the methodological validation study by Quinete et al. 2015.

Table 1B. Differences between women with and without RLS

\begin{tabular}{|c|c|c|c|}
\hline & $\begin{array}{c}\text { RLS } \\
(n=57)\end{array}$ & $\begin{array}{l}\text { No RLS } \\
(n=251)\end{array}$ & $p$ \\
\hline & $\mathrm{M}(\mathrm{SD})$ & $\mathrm{M}(\mathrm{SD})$ & \\
\hline Age & $33.18(4.66)$ & $31.47(4.608)$ & .012 \\
\hline Depression score EPDS T0 & $4.72(4.02)$ & $5.01(3.53)$ & .583 \\
\hline Depression score EPDS T1 & $3.77(3.23)$ & $4.00(4.03)$ & .690 \\
\hline Hair Cortisol Concentration (HCC) T0 (in pg/mg) & $11.45(16.14)$ & $9.36(11.54)$ & .260 \\
\hline Hair Cortisol Concentration (HCC) T1 (in pg/mg) & $5.97(5.95)$ & $13.65(95.70)$ & .549 \\
\hline Hemoglobin in g/dL T0 & $12.06(1.13)$ & $11.94(1.18)$ & .483 \\
\hline Length of pregnancy in days & $272.65(9.96)$ & $272.66(13.50)$ & .997 \\
\hline \multirow[t]{2}{*}{ Child's birth weight (in gram) } & $3315.69(501.96)$ & 3326.28 (571.94) & .902 \\
\hline & $n(\%)$ & $n(\%)$ & \\
\hline Family Status & & & .047 \\
\hline Married & $36(63.2)$ & $190(76)$ & \\
\hline Unmarried & $21(36.8)$ & $60(24)$ & \\
\hline Number of children & & & .186 \\
\hline 1 & $26(45.6)$ & $137(55)$ & \\
\hline 2 & $21(36.8)$ & $86(34.5)$ & \\
\hline 3 & $6(10.5)$ & $22(8.8)$ & \\
\hline 4 & $3(5.3)$ & $3(1.2)$ & \\
\hline 5 & $1(1.8)$ & $1(0.4)$ & \\
\hline Highest education & & & .511 \\
\hline
\end{tabular}


medRxiv preprint doi: https://doi.org/10.1101/2020.07.21.20158634; this version posted July 22, 2020. The copyright holder for this preprint (which was not certified by peer review) is the author/funder, who has granted medRxiv a license to display the preprint in perpetuity.

It is made available under a CC-BY-NC-ND 4.0 International license .

No school graduation

Secondary school degree

Junior high school degree

University entrance

$\begin{array}{cc}1(1.8) & 2(0.8) \\ 3(5.3) & 8(3.3) \\ 5(8.8) & 38(15.6) \\ 26(45.6) & 120(49.4)\end{array}$

$16(28.1)$

$61(25.1)$

$6(10.5)$

$14(5.8)$

Doctoral degree

Birth mode

\begin{tabular}{|c|c|c|c|}
\hline Spontaneous & $31(54.4)$ & $142(56.6)$ & \\
\hline Ventouse & $4(7)$ & $15(6)$ & \\
\hline Section & $13(22.8)$ & $65(25.9)$ & \\
\hline Emergency section & $9(15.8)$ & $29(11.6)$ & \\
\hline Breastfeeding at $\mathrm{T} 0$ & $49(86)$ & $221(88)$ & .666 \\
\hline \multicolumn{4}{|l|}{ Pregnancy-related complications } \\
\hline Pre-eclampsia / Hypertension & $4(7.0)$ & $13(5.2)$ & .583 \\
\hline Gestational Diabetes & $11(19.3)$ & $29(11.6)$ & .049 \\
\hline Child relocation after birth & $69(27.6)$ & $17(29.8)$ & .603 \\
\hline Iron supplements & $32(58.2)$ & - & \\
\hline RLS in previous pregnancy & $20(35.0)$ & - & \\
\hline \multicolumn{4}{|l|}{ Most severe RLS symptoms } \\
\hline First trimester & $2(3.51)$ & - & \\
\hline Second trimester & $7(12.28)$ & - & \\
\hline Third trimester & $38(66.67)$ & - & \\
\hline Equally high over all trimesters & $8(14.04)$ & - & \\
\hline Psychiatric history & $11(19.3)$ & $41(16.4)$ & .599 \\
\hline Baby blues & $30(52.6)$ & $108(43.7)$ & .223 \\
\hline Stressful life events (SLESQ) & $35(61.4)$ & $103(41.4)$ & .006 \\
\hline
\end{tabular}

Notes. $n=$ absolute frequency, $\mathrm{M}=$ mean, $\mathrm{SD}=$ standard deviation

Table 1C. Demographics of women with RLS and their matched counterparts, in accordance with Figure 1

\begin{tabular}{|l|c|c|c|c|c|c|c|c|}
\hline & Details & \multicolumn{4}{c|}{ RLS $(\boldsymbol{n}=\mathbf{5 7})$} & \multicolumn{3}{c|}{$\begin{array}{c}\text { Matched women without } \\
\text { RLS (n= 26) }\end{array}$} \\
\hline & & Min & Max & M (SD) & Min & Max & M (SD) \\
\hline Age & 23 & 42 & 33.18 & 24 & 40 & 32.12 \\
\hline $\begin{array}{l}\text { Total number } \\
\text { of children }\end{array}$ & & & & $(4.66)$ & & & $(4.13)$ \\
\hline
\end{tabular}


medRxiv preprint doi: https://doi.org/10.1101/2020.07.21.20158634; this version posted July 22,2020 . The copyright holder for this preprint (which was not certified by peer review) is the author/funder, who has granted medRxiv a license to display the preprint in perpetuity.

It is made available under a CC-BY-NC-ND 4.0 International license .

\begin{tabular}{|c|c|c|c|c|c|c|c|}
\hline $\begin{array}{l}\text { Highest degree } \\
\text { of education }\end{array}$ & $\begin{array}{l}\text { None (0), secondary school } \\
\text { (1), junior high school degree } \\
\text { (2), university entrance (3), } \\
\text { college degree (4), doctoral } \\
\text { degree (5) }\end{array}$ & 0 & 5 & $\begin{array}{c}3.24 \\
(1.07)\end{array}$ & 1 & 5 & $\begin{array}{c}3.19 \\
(0.849)\end{array}$ \\
\hline Income & $\begin{array}{l}\text { In keuros/year; <10k (1), } \\
<20 \mathrm{k}(2),<50 \mathrm{k}(3),>50 \mathrm{k}(4)\end{array}$ & 1 & 4 & $\begin{array}{l}3.42 \\
(0.74)\end{array}$ & 2 & 4 & $\begin{array}{c}3.54 \\
(0.71)\end{array}$ \\
\hline $\begin{array}{l}\text { Days of } \\
\text { gestation }\end{array}$ & & 239 & 288 & $\begin{array}{c}272.65 \\
(9.96)\end{array}$ & 238 & 287 & $\begin{array}{c}273 \\
(12.39)\end{array}$ \\
\hline $\begin{array}{l}\text { Birthweight of } \\
\text { child }\end{array}$ & In gram & 2130 & 4290 & $\begin{array}{l}3315.69 \\
(501.96)\end{array}$ & 2090 & 4395 & $\begin{array}{l}3417.69 \\
(518.13)\end{array}$ \\
\hline $\begin{array}{l}\text { Number of } \\
\text { stressful life } \\
\text { events }\end{array}$ & & 0 & 7 & $\begin{array}{c}1.44 \\
(1.76)\end{array}$ & 0 & 2 & $\begin{array}{c}0.31 \\
(0.62)\end{array}$ \\
\hline $\begin{array}{l}\text { Total IRLSS } \\
\text { score T0 }\end{array}$ & Severity of RLS in pregnancy & 5 & 36 & $\begin{array}{l}17.95 \\
(7.28)\end{array}$ & - & - & - \\
\hline $\begin{array}{l}\text { Total IRLSS } \\
\text { score T1 }\end{array}$ & $\begin{array}{l}\text { Severity of RLS } 12 \text { weeks } \\
\text { postpartum }\end{array}$ & 0 & 29 & $\begin{array}{c}5.42 \\
(8.60)\end{array}$ & - & - & - \\
\hline HCC T0 & & 1.33 & 77.84 & $\begin{array}{l}11.45 \\
(16.14)\end{array}$ & 1.52 & 73.95 & $\begin{array}{c}11.59 \\
(14.98)\end{array}$ \\
\hline EPDS score T0 & & 0 & 19 & $\begin{array}{c}4.72 \\
(4.02)\end{array}$ & 0 & 9 & $\begin{array}{c}4.27 \\
(2.65)\end{array}$ \\
\hline & & \multicolumn{3}{|c|}{$n(\%)$} & \multicolumn{3}{|c|}{$n(\%)$} \\
\hline \multirow{2}{*}{$\begin{array}{l}\text { RLS in } \\
\text { previous } \\
\text { pregnancy }\end{array}$} & & \multicolumn{3}{|c|}{$20(35.1)$} & \multicolumn{3}{|c|}{0} \\
\hline & & Min & Max & M (SD) & Min & Max & M (SD) \\
\hline Q1 & $\begin{array}{l}\text { How would you rate the RLS- } \\
\text { related unpleasant sensations } \\
\text { in your legs or arms? }\end{array}$ & 1 & 4 & $\begin{array}{l}2.24 \\
(0.96)\end{array}$ & - & - & - \\
\hline Q2 & $\begin{array}{l}\text { How would you rate your } \\
\text { urge to move because of the } \\
\text { unpleasant sensations? }\end{array}$ & 1 & 4 & $\begin{array}{c}2.56 \\
(0.96)\end{array}$ & - & - & - \\
\hline Q3 & $\begin{array}{l}\text { To what extent were the } \\
\text { unpleasant sensations in your } \\
\text { legs or arms alleviated by } \\
\text { exercise? }\end{array}$ & 0 & 3 & $\begin{array}{l}1.75 \\
(0.80)\end{array}$ & - & - & - \\
\hline Q4 & $\begin{array}{l}\text { How badly was your sleep } \\
\text { affected by the unpleasant } \\
\text { sensations? }\end{array}$ & 0 & 4 & $\begin{array}{l}1.87 \\
(1.44)\end{array}$ & - & - & - \\
\hline Q5 & $\begin{array}{l}\text { How tired or sleepy were you } \\
\text { during the day because of the } \\
\text { unpleasant sensations? }\end{array}$ & 0 & 4 & $\begin{array}{c}1.36 \\
(1.24)\end{array}$ & - & - & - \\
\hline Q6 & $\begin{array}{l}\text { Overall, how strong were the } \\
\text { unpleasant sensations? }\end{array}$ & 1 & 4 & $2(0.82)$ & - & - & - \\
\hline Q7 & $\begin{array}{l}\text { How often did the unpleasant } \\
\text { sensations occur? }\end{array}$ & 1 & 4 & $\begin{array}{l}2.53 \\
(0.94)\end{array}$ & - & - & - \\
\hline Q8 & $\begin{array}{c}\text { If you had unpleasant } \\
\text { sensations, how severe were } \\
\text { they on average? }\end{array}$ & 1 & 4 & $2(0.77)$ & - & - & - \\
\hline
\end{tabular}


medRxiv preprint doi: https://doi.org/10.1101/2020.07.21.20158634; this version posted July 22,2020 . The copyright holder for this preprint (which was not certified by peer review) is the author/funder, who has granted medRxiv a license to display the preprint in perpetuity.

It is made available under a CC-BY-NC-ND 4.0 International license .

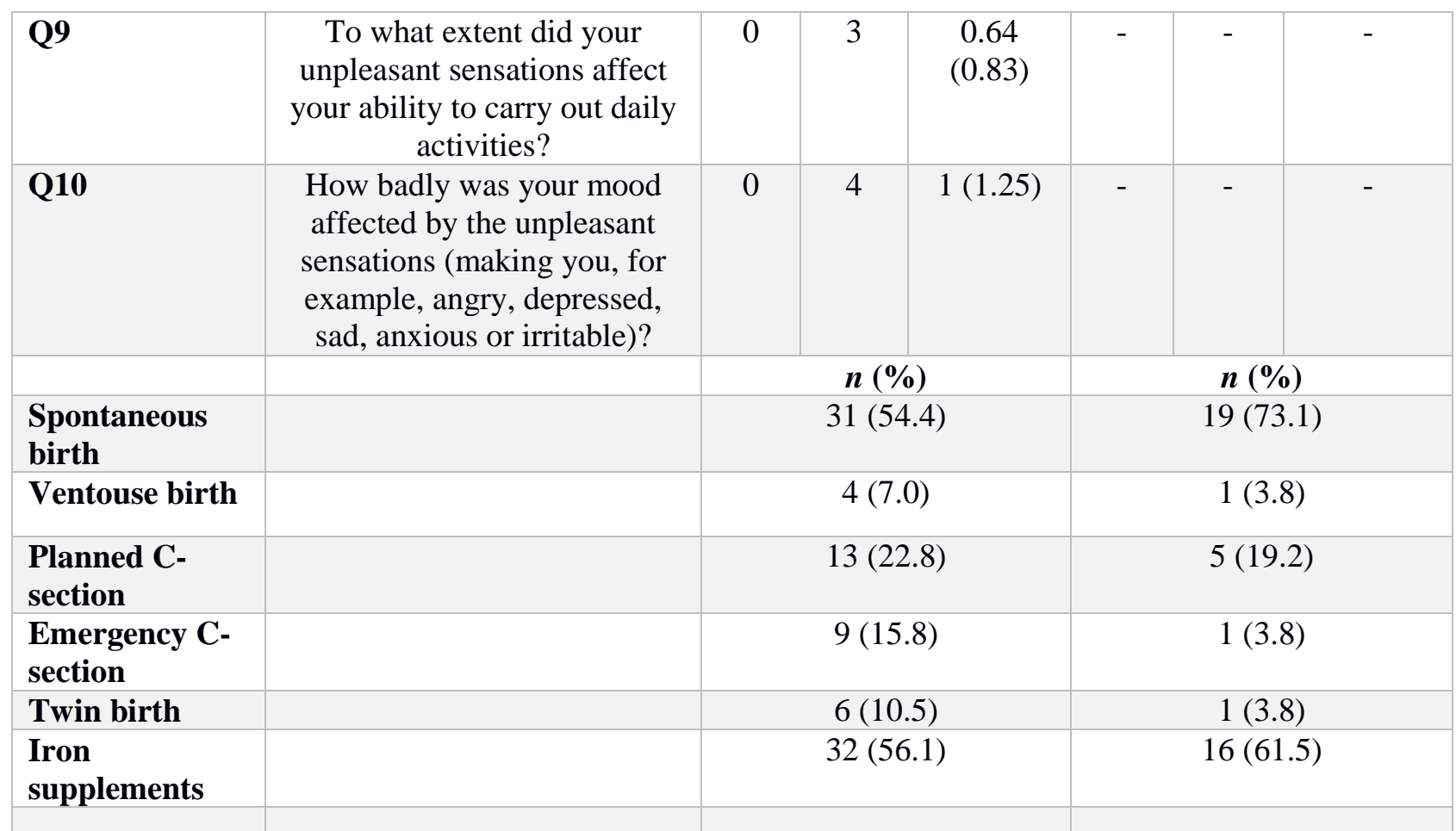

Notes: $n=$ absolute frequency, $\%=$ relative frequency, $\mathrm{M}=$ mean, $\mathrm{SD}=$ standard deviation, $\mathrm{Md}=$ median,

Min $=$ Minimum, Max $=$ Maximum, IRLSS $=$ International Restless Legs Syndrome Scale, SLESQ $=$ Stressful

Life Events Screening Questionnaire; EPDS= Edinburgh Postnatal Depression Scale, HCC = hair cortisol concentration, $\mathrm{T} 0=$ baseline measure in childbed 
medRxiv preprint doi: https://doi.org/10.1101/2020.07.21.20158634; this version posted July 22, 2020. The copyright holder for this preprint (which was not certified by peer review) is the author/funder, who has granted medRxiv a license to display the preprint in perpetuity.

It is made available under a CC-BY-NC-ND 4.0 International license.

Table 2. Demographics of women with RLS participated on MRI, in accordance with Figures 2 and 3

\begin{tabular}{|c|c|c|c|c|}
\hline \multirow[t]{2}{*}{ Variables } & \multicolumn{3}{|c|}{ Descriptive statistics } & \multirow[t]{2}{*}{ Details } \\
\hline & Min & Max & $\begin{array}{c}\text { Mean } \\
\text { (SD) }\end{array}$ & \\
\hline Age & 23 & 42 & $\begin{array}{l}33.08 \\
(5.84)\end{array}$ & \\
\hline \multirow[t]{2}{*}{ Total number of children } & 1 & 5 & $\begin{array}{c}2.04 \\
(1.23)\end{array}$ & \\
\hline & Min & Max & Mode & \\
\hline Highest degree of education & 0 & 5 & 3 & $\begin{array}{l}\text { None }(0) \text {, secondary school }(1) \text {, } \\
\text { junior high school degree }(2) \text {, } \\
\text { university entrance }(3) \text {, college } \\
\text { degree (4), doctoral degree }(5)\end{array}$ \\
\hline \multirow[t]{2}{*}{ Income } & 1 & 4 & 3 & $\begin{array}{l}\text { In euros/year; <10k (1), <20k (2), } \\
<50 \mathrm{k}(3),>50 \mathrm{k}(4)\end{array}$ \\
\hline & Min & Max & $\begin{array}{l}\text { Mean } \\
\text { (SD) }\end{array}$ & \\
\hline Days of gestation & 239 & 288 & $\begin{array}{c}274 \\
(10.97)\end{array}$ & \\
\hline Birth weight of child & 2700 & 6300 & $\begin{array}{c}3704 \\
(847.77)\end{array}$ & In gram \\
\hline Number of stressful life events & 0 & 6 & $\begin{array}{c}1.2 \\
(1.56)\end{array}$ & \\
\hline IRLSS score T0 & 7 & 28 & $\begin{array}{l}16.87 \\
(6.26)\end{array}$ & $\begin{array}{l}\text { Severity of RLS symptoms in } \\
\text { pregnancy }\end{array}$ \\
\hline IRLSS score T1 & 0 & 29 & $\begin{array}{c}7.2 \\
(9.82)\end{array}$ & $\begin{array}{l}\text { Severity of RLS symptoms } 12 \\
\text { weeks postpartum }\end{array}$ \\
\hline HCC T0 & 1.32 & 77.84 & $\begin{array}{c}9.2 \\
(15.38)\end{array}$ & \\
\hline EPDS score T0 & 0 & 11 & $\begin{array}{c}4.37 \\
(3.46)\end{array}$ & \\
\hline RLS in previous pregnancy & 0 & 2 & $\begin{array}{l}1.12 \\
(0.79)\end{array}$ & \\
\hline $\begin{array}{l}\text { Q1. How would you rate the RLS- } \\
\text { related unpleasant sensations in your } \\
\text { legs or arms? }\end{array}$ & 1 & 3 & $\begin{array}{c}2.08 \\
(0.77)\end{array}$ & \\
\hline $\begin{array}{l}\text { Q2. How would you rate your urge to } \\
\text { move because of the unpleasant } \\
\text { sensations? }\end{array}$ & 1 & 4 & $\begin{array}{c}2.37 \\
(0.92)\end{array}$ & \\
\hline $\begin{array}{l}\text { Q3. To what extent were the unpleasant } \\
\text { sensations in your legs or arms alleviated } \\
\text { by exercise? }\end{array}$ & 1 & 3 & $\begin{array}{c}1.71 \\
(0.75)\end{array}$ & \\
\hline $\begin{array}{l}\text { Q4. How badly was your sleep affected } \\
\text { by the unpleasant sensations? }\end{array}$ & 0 & 4 & $\begin{array}{c}1.96 \\
(1.43)\end{array}$ & \\
\hline $\begin{array}{l}\text { Q5. How tired or sleepy were you during } \\
\text { the day because of the unpleasant } \\
\text { sensations? }\end{array}$ & 0 & 4 & $\begin{array}{c}1.37 \\
(1.13)\end{array}$ & \\
\hline $\begin{array}{l}\text { Q6. Overall, how strong were the } \\
\text { unpleasant sensations? }\end{array}$ & 1 & 3 & $\begin{array}{c}1.96 \\
(0.69)\end{array}$ & \\
\hline $\begin{array}{l}\text { Q7. How often did the unpleasant } \\
\text { sensations occur? }\end{array}$ & 0 & 4 & $\begin{array}{c}2.42 \\
(0.93)\end{array}$ & \\
\hline
\end{tabular}


medRxiv preprint doi: https://doi.org/10.1101/2020.07.21.20158634; this version posted July 22,2020 . The copyright holder for this preprint (which was not certified by peer review) is the author/funder, who has granted medRxiv a license to display the preprint in perpetuity.

It is made available under a CC-BY-NC-ND 4.0 International license .

\begin{tabular}{|l|c|c|c|c|}
\hline $\begin{array}{l}\text { Q8. If you had unpleasant sensations, } \\
\text { how severe were they on average? }\end{array}$ & 0 & 2 & $\begin{array}{c}0.46 \\
(0.58)\end{array}$ & \\
\hline $\begin{array}{l}\text { Q9. To what extent did your unpleasant } \\
\text { sensations affect your ability to carry out } \\
\text { daily activities? }\end{array}$ & 0 & 2 & $\begin{array}{c}0.46 \\
(0.58)\end{array}$ & \\
\hline $\begin{array}{l}\text { Q10. How badly was your mood } \\
\text { affected by the unpleasant sensations } \\
\text { (making you, for example, angry, }\end{array}$ & 0 & 3 & $\begin{array}{c}0.71 \\
(0.91)\end{array}$ & \\
\hline depressed, sad, anxious or irritable)? & & & \\
\hline No birth-related complications & $17(68.00)$ & \\
\hline Birth-related complications & $8(32.00)$ & \\
\hline No pregnancy-related complications & $11(44.00)$ & \\
\hline Pregnancy-related complications & $14(56.00)$ & \\
\hline With partner, not married & $12(48.00)$ & \\
\hline With partner, married & $13(52.00)$ & \\
\hline No breastfeeding & $6(24.00)$ & \\
\hline Breastfeeding & $19(76.00)$ & \\
\hline No relocation of child to other ward & $18(72.00)$ & \\
\hline Relocation of child to other ward & $7(28.00)$ & \\
\hline Birth of a single child & $21(84.00)$ & \\
\hline Twin birth & $4(16.00)$ & \\
\hline No iron supplements & $9(36.00)$ & \\
\hline Iron supplements & $16(64.00)$ & \\
\hline & & \\
\hline
\end{tabular}

